\title{
Disproportionation of O-Benzylhydroxylamine Catalyzed by a Ferric Bis- Picket Fence Porphyrin Complex
}

\author{
Ashley B. McQuarters, ${ }^{[a]}$ Lauren E. Goodrich, ${ }^{[a]}$ Claire M. Goodrich, ${ }^{[a]}$ and \\ Nicolai Lehnert*[a]
}

Keywords: Hydroxylamine; Ferric porphyrins; Nitrogen cycle; UV/Vis spectroscopy; Ammonia complexes

\begin{abstract}
Hydroxylamine $\left(\mathrm{NH}_{2} \mathrm{OH}\right)$ is an important molecule in biology that serves as an intermediate in the nitrogen cycle, and that can also be utilized as a nitric oxide donor in mammals under certain conditions. In light of this, the interaction of $\mathrm{NH}_{2} \mathrm{OH}$ with hemes in proteins and model systems has gained much attention recently. In this study, we use the more stable, oxygen substituted O-benzylhydroxylamine $\left(\mathrm{NH}_{2} \mathrm{OBn}\right)$ as a model for $\mathrm{NH}_{2} \mathrm{OH}$. Here, the reactivity of the ferric bis-picket fence porphyrin complexes [ $\left.\mathrm{Fe}(3,5-\mathrm{Me}-\mathrm{BAFP})\left(\mathrm{ClO}_{4}\right)\right]$ (1) and $\left[\mathrm{Fe}(3,5-\mathrm{Me}-\mathrm{BAFP})\left(\mathrm{PF}_{6}\right)\right]$ (2) (3,5-Me-BAFP ${ }^{2-}=$ dianion of tetra(2,6-bis(3,5-dimethylphenoxy)phenyl)porphyrin)) with $\mathrm{NH}_{2} \mathrm{OBn}$
\end{abstract}

\section{Introduction}

The small molecule hydroxylamine $\left(\mathrm{NH}_{2} \mathrm{OH}\right)$ plays an important role in biological systems, both as a metabolite, formed from the decomposition of nitrosothiols in mammals, ${ }^{[1]}$ and as an intermediate in the nitrogen cycle. ${ }^{[2]}$ Examples for the latter include ammonia to nitrite interconversions in bacteria. For example, in nitrification, the autotrophic bacterium Nitrosomas europea converts $\mathrm{NH}_{3}$ to $\mathrm{NO}_{2}^{-}$to gain energy needed for growth. This is a two-step process that is carried out by two enzymes: the membrane-bound enzyme ammonia monooxygenase which oxidizes $\mathrm{NH}_{3}$ to $\mathrm{NH}_{2} \mathrm{OH}$ as shown in Equation (1), and a soluble, multi-heme containing enzyme, hydroxylamine oxidoreductase, which is responsible for nitrite generation as shown in Equation (2). ${ }^{[3,4]}$ The reverse process is facilitated by assimilatory siroheme-based nitrite reductases, which catalyze the direct six-electron reduction of $\mathrm{NO}_{2}^{-}$to $\mathrm{NH}_{3}$ in one step, i.e. without the release of partially reduced intermediates as shown in Equation (3). ${ }^{[5]}$ In light of this, interest has grown recently to investigate the reactivity of $\mathrm{NH}_{2} \mathrm{OH}$ with metal complexes, especially hemes, to understand the coordination chemistry of hydroxylamine ligands and their reactivity. ${ }^{[6]}$

$\mathrm{NH}_{3}+\mathrm{O}_{2}+2 \mathrm{e}^{-}+2 \mathrm{H}^{+} \rightarrow \mathrm{NH}_{2} \mathrm{OH}+\mathrm{H}_{2} \mathrm{O}$

* Prof. Dr. N. Lehnert

E-Mail: lehnertn@umich.edu

[a] Department of Chemistry

University of Michigan

Ann Arbor, MI 48109, USA

Supporting information for this article is available on the WWW under http://dx.doi.org/10.1002/zaac.201300125 or from the author. is investigated. The product of these reactions is characterized by UV/Vis and EPR spectroscopy and X-ray crystallography. We found that addition of excess $\mathrm{NH}_{2} \mathrm{OBn}$ to our ferric porphyrin complexes results in reduction of the heme to the ferrous oxidation state. This is followed by disproportionation of additional $\mathrm{NH}_{2} \mathrm{OBn}$ to yield the ferrous complex $\left[\mathrm{Fe}(3,5-\mathrm{Me}-\mathrm{BAFP})\left(\mathrm{NH}_{3}\right)_{2}\right](3)$ as the final product. The crystal structure of (3) constitutes the first structural characterization of a bis-ammonia complex of a ferrous heme. The stability of this complex may be facilitated by the picket fences of the porphyrin ligand used here.
$\mathrm{NH}_{2} \mathrm{OH}+\mathrm{H}_{2} \mathrm{O} \rightarrow \mathrm{NO}_{2}^{-}+4 \mathrm{e}^{-}+5 \mathrm{H}^{+}$

$\mathrm{NO}_{2}^{-}+7 \mathrm{H}^{+}+6 \mathrm{e}^{-} \rightarrow \mathrm{NH}_{3}+2 \mathrm{H}_{2} \mathrm{O}$

At this point it should be noted that $\mathrm{NH}_{2} \mathrm{OH}$ is unstable, and must be carefully handled at low temperatures (in its free base form) to prevent spontaneous decomposition into $\mathrm{NH}_{3}, \mathrm{~N}_{2}$, and/or $\mathrm{N}_{2} \mathrm{O}{ }^{[7]}$ The first step in $\mathrm{NH}_{2} \mathrm{OH}$ decomposition is the formation of $\mathrm{NH}_{3}$ and $\mathrm{HNO}$ [Equation (4)].

Further reactivity of $\mathrm{HNO}$ is dependent on the $\mathrm{pH}$ of the solution. In an alkaline solution, $\mathrm{HNO}$ reacts with $\mathrm{NH}_{2} \mathrm{OH}$ to form $\mathrm{N}_{2}$ as shown in Equation (5). While in an acidic medium, HNO reacts with $\mathrm{NH}_{2} \mathrm{OH}$ to form $\mathrm{H}_{2} \mathrm{~N}_{2} \mathrm{O}_{2}$, which subsequently decomposes into $\mathrm{N}_{2} \mathrm{O}$ and $\mathrm{H}_{2} \mathrm{O}$ [Equation (6)]. ${ }^{[7]}$

$2 \mathrm{NH}_{2} \mathrm{OH} \rightarrow \mathrm{H}_{2} \mathrm{O}+\mathrm{NH}_{3}+\mathrm{HNO}$

$\mathrm{HNO}+\mathrm{NH}_{2} \mathrm{OH} \rightarrow \mathrm{N}_{2}+2 \mathrm{H}_{2} \mathrm{O}$

$\mathrm{HNO}+2 \mathrm{NH}_{2} \mathrm{OH} \rightarrow \mathrm{H}_{2} \mathrm{~N}_{2} \mathrm{O}_{2}+\mathrm{NH}_{3}+\mathrm{H}_{2} \mathrm{O}$

In lieu of this, it is not surprising that there is only one report of an $\mathrm{NH}_{2} \mathrm{OH}$-bound ferrous heme model complex, $\left[\mathrm{Fe}(\mathrm{TPP})\left(\mathrm{NH}_{2} \mathrm{OH}\right)_{2}\right] \quad(\mathrm{TPP}=$ dianion of tetraphenylporphyrin). ${ }^{[8]}$ However, $\left[\mathrm{Fe}(\mathrm{TPP})\left(\mathrm{NH}_{2} \mathrm{OH}\right)_{2}\right]$ is only marginally stable at $-30{ }^{\circ} \mathrm{C}$ in dichloromethane and was never isolated. This complex was characterized in solution at $-30{ }^{\circ} \mathrm{C}$ by ${ }^{1} \mathrm{H}-$ NMR and UV/Vis spectroscopy and Cyclic Voltammetry. ${ }^{[8]}$ Interestingly, Feng and Ryan found that the reaction of excess $\mathrm{NH}_{2} \mathrm{OH}$ with the ferric porphyrin complexes $[\mathrm{Fe}(\mathrm{TPP})(\mathrm{X})]$ $\left(\mathrm{X}=\mathrm{Cl}^{-}, \quad \mathrm{NO}_{3}^{-}\right),[\mathrm{Fe}(\mathrm{OEP})(\mathrm{Cl})]$, and $[\mathrm{Fe}(\mathrm{PPDME})(\mathrm{Cl})]$ $\left(\mathrm{OEP}^{2-}=\right.$ dianion of octaethylporphyrin, $\mathrm{PPDME}^{2-}=$ dianion of protoporphyrin(IX) dimethyl ester), and with the ferrous porphyrin $[\mathrm{Fe}(\mathrm{TPP})]$ at room temperature generates in each 
case a ferrous heme-nitrosyl complex in over $80 \%$ yield as the final product (both in dichloromethane ${ }^{[8]}$ and in chloroform/ methanol mixtures $\left.{ }^{[6 \mathrm{c}]}\right)$. The other major reaction product is $\mathrm{NH}_{3}$, as an approx. 10 fold excess of $\mathrm{NH}_{3}$ was detected in solution. ${ }^{[6 \mathrm{c}]}$

More recently, Bari et al. reported kinetic investigations into the mechanism of $\mathrm{NH}_{2} \mathrm{OH}$ disproportionation in an aqueous environment by water-soluble ferric porphyrin complexes, and the determination of the nitrogen-containing reaction products. $^{[6 \mathrm{~b}]}$ In this study, the ferric porhyrins $[\mathrm{Fe}(\mathrm{TPPS})]^{3-}$, $[\mathrm{Fe}(\mathrm{MP} 11)]$, and $[\mathrm{Fe}(\mathrm{TEPyP})]^{5+}$ (TPPS $^{6-}=$ dianion of tetra(4sulfonatophenyl)porphyrin, MP11 = microperoxidase 11, $\mathrm{TEPyP}^{2+}=$ dianion of tetra $(N$-ethylpyridinium-2yl $)$ porphyrin $)$ were reacted with excess $\mathrm{NH}_{2} \mathrm{OH}$ at room temperature. When $\mathrm{NH}_{2} \mathrm{OH}$ was reacted with the ferric porphyrin complexes, $\mathrm{NH}_{3}, \mathrm{~N}_{2} \mathrm{O}$, and $\mathrm{N}_{2}$ were detected as the main products (also minor amounts of $\mathrm{NO}_{2}^{-}$), while nitric oxide (NO) was not observed as a gaseous product. With increasing concentrations of $\mathrm{NH}_{2} \mathrm{OH}, \mathrm{N}_{2}$ becomes the more dominant product compared to $\mathrm{N}_{2} \mathrm{O}$, most notably for [Fe(MP11)]. Additionally, the reactivity of $\mathrm{NH}_{2} \mathrm{OH}$ with these ferric porphyrins was studied by UV/ Vis and ${ }^{1} \mathrm{H}-\mathrm{NMR}$ spectroscopy. Interestingly, despite the fact that $\mathrm{NO}$ was not detected as a gaseous product, when $\mathrm{NH}_{2} \mathrm{OH}$ is reacted with the ferric complex $[\mathrm{Fe}(\mathrm{TPPS})]^{3-}$, the UV/Vis spectrum of the product matches that of the ferrous heme-nitrosyl $[\mathrm{Fe}(\mathrm{TPPS})(\mathrm{NO})]^{4-}$, which agrees with the results by Feng and Ryan. In contrast to the latter report, the conversion to the ferrous heme-nitrosyl product was not quantitative, and with time oxidation of the ferrous complex occurred to regenerate the starting ferric porphyrin complex. Curiously, the addition of $\mathrm{NH}_{2} \mathrm{OH}$ to the ferric complexes [Fe(MP11)] and $[\mathrm{Fe}(\mathrm{TEPyP})]^{5+}$ did not lead to a ferrous heme-nitrosyl; instead, a different ferrous reaction product was observed. The identity of this ferrous reaction product could not be determined based on UV/Vis and ${ }^{1} \mathrm{H}-\mathrm{NMR}$ spectroscopy. In summary, reaction of ferric porphyrins with excess $\mathrm{NH}_{2} \mathrm{OH}$ first leads to reduction to the ferrous oxidation state, followed by disproportionation of excess $\mathrm{NH}_{2} \mathrm{OH}$. The reaction products vary based on the nature of the heme and the reaction conditions, but are mostly $\mathrm{N}_{2}, \mathrm{~N}_{2} \mathrm{O}, \mathrm{NH}_{3}$, and $\mathrm{H}_{2} \mathrm{O}$.

With only one report of a ferrous porphyrin hydroxylamine complex in hand, which is only marginally stable and not well characterized, it is important to further investigate the reactivity of hydroxylamine ligands with iron porphyrin complexes. One way to potentially increase the stability of $\mathrm{NH}_{2} \mathrm{OH}$ is by functionalization of the oxygen atom of this molecule. Corresponding $\mathrm{NH}_{2} \mathrm{OR}$ ligands are commercially available (as the hydrochloride salts) and stable at room temperature. In theory, this may help to generate more stable $\mathrm{NH}_{2} \mathrm{OR}$ complexes of iron porphyrins and to further elucidate the intrinsic reactivity of these species.

In this study, we explore the reactivity of $\mathrm{NH}_{2} \mathrm{OBn}$ with a ferric bis-picket fence porphyrin complex in attempts to synthesize $\left[\mathrm{Fe}(3,5-\mathrm{Me}-\mathrm{BAFP})\left(\mathrm{NH}_{2} \mathrm{OBn}\right)_{2}\right]\left(3,5-\mathrm{Me}-\mathrm{BAFP}^{2-}=\mathrm{di}-\right.$ anion of tetra(2,6-bis(3,5-dimethylphenoxy)phenyl)porphyrin). Here, the picket fence of the porphyrin ligand is useful to potentially stabilize the desired $\mathrm{NH}_{2} \mathrm{OBn}$ complex, and to prevent unfavorable side reactions. We find that $\mathrm{NH}_{2} \mathrm{OBn}$ reduces the ferric porphyrin complex to the ferrous oxidation state, which then catalyzes the disproportionation of excess $\mathrm{NH}_{2} \mathrm{OBn}$ to generate $\mathrm{NH}_{3}$ and benzyl alcohol. We have characterized the reaction product and identified it as $\left[\mathrm{Fe}(3,5-\mathrm{Me}-\mathrm{BAFP})\left(\mathrm{NH}_{3}\right)_{2}\right]$ via X-ray crystallography, which, to the best of our knowledge, is the first report of a crystal structure of an ammonia-bound ferrous porphyrin model complex.

\section{Experimental Procedures}

All reactions were performed under inert conditions using Schlenk techniques. Preparation and handling of air sensitive materials was carried out under a nitrogen atmosphere in an MBraun glovebox equipped with a circulating purifier $\left(\mathrm{O}_{2}, \mathrm{H}_{2} \mathrm{O}<0.1 \mathrm{ppm}\right)$.

All solvents were distilled from $\mathrm{CaH}_{2}$ under nitrogen, then degassed via four freeze-pump-thaw cycles. The purified solvents were stored in the glovebox until used. O-Benzylhydroxylamine ${ }^{[9]}$ and $[\mathrm{Fe}(3,5-\mathrm{Me}-\mathrm{BAFP})(\mathrm{Cl})]^{[10]}$ were prepared using reported procedures.

Synthesis of [Fe(3,5-Me-BAFP) $\left.\left(\mathrm{ClO}_{4}\right)\right]$ : $\left[\mathrm{Fe}(3,5-\mathrm{Me}-\mathrm{BAFP})\left(\mathrm{ClO}_{4}\right)\right]$ was synthesized using a modified literature procedure. ${ }^{[11]}$ [Fe(3,5-Me-BAFP)(Cl)] (286 mg, $0.172 \mathrm{mmol})$ and silver perchlorate (36 mg, $0.172 \mathrm{mmol}$ ) were dissolved in 2-methyltetrahydrofuran $(17 \mathrm{~mL})$. The reaction mixture was heated to reflux for $1 \mathrm{~h}$ and filtered hot through a fine frit. The filtrate was layered with hexanes $(30 \mathrm{~mL})$ and allowed to precipitate at $-30^{\circ} \mathrm{C}$. After 20 hours, the resulting purple crystalline material was filtered off and vacuum dried for 4 hours. Yield: $185 \mathrm{mg}(62 \%)$. UV/Vis $\left(\mathrm{CH}_{2} \mathrm{Cl}_{2}\right): 405,524,593,623 \mathrm{~nm}$. UV/Vis (toluene): 416, 515, 597, $661 \mathrm{~nm}$. IR $(\mathrm{KBr}): \tilde{v}=\left(\mathrm{ClO}_{4}\right): 1096$, $623 \mathrm{~cm}^{-1}$.

Synthesis of $\left[\mathbf{F e}(\mathbf{3 , 5}-\mathrm{Me}-\mathrm{BAFP})\left(\mathbf{P F}_{\mathbf{6}}\right)\right]: \quad[\mathrm{Fe}(3,5-\mathrm{Me}-\mathrm{BAFP})(\mathrm{Cl})]$ (695 mg, $0.417 \mathrm{mmol}$ ) and silver hexafluorophosphate (106 mg, $0.419 \mathrm{mmol})$ were dissolved in 2-methyltetrahydrofuran $(30 \mathrm{~mL})$. The reaction mixture was heated to reflux for $2 \mathrm{~h}$ and filtered through a fine frit. The filtrate was layered with hexanes $(90 \mathrm{~mL})$ and allowed to precipitate at $-30{ }^{\circ} \mathrm{C}$. After 24 hours, the resulting purple crystalline solid was filtered off and vacuum dried overnight. Yield: $580 \mathrm{mg}$ (78\%). UV/Vis (toluene): 414, 517, 596, $663 \mathrm{~nm} . \quad$ UV/Vis (2-Me-THF): 401, 523, 589, $655 \mathrm{~nm}$. IR $(\mathrm{KBr}): \tilde{v}=\left(\mathrm{PF}_{6}\right): 842$, $557 \mathrm{~cm}^{-1} .{ }^{19} \mathbf{F}\left\{{ }^{1} \mathbf{H}\right\}$ NMR $\left(\mathrm{CDCl}_{3}\right):-81.17\left(\mathrm{~d}, J_{\mathrm{PF}}=713 \mathrm{~Hz}\right)$.

Crystallization of $\left[\mathrm{Fe}(3,5-\mathrm{Me}-\mathrm{BAFP})\left(\mathrm{NH}_{3}\right)_{2}\right]$ : In a $5 \mathrm{~mm}$ diameter glass tube, $\left[\mathrm{Fe}(3,5-\mathrm{Me}-\mathrm{BAFP})\left(\mathrm{ClO}_{4}\right)\right](5 \mathrm{mg})$ and O-benzylhydroxylamine (approx. 5 equivalents) were dissolved in toluene $(0.2 \mathrm{~mL})$. The mixture was layered carefully with hexanes $(1.5 \mathrm{~mL})$ and closed with a rubber septum. After 5 days, brown prisms suitable for X-ray analysis were collected.

Quantification of $\mathbf{N H}_{3}$ : The reagents for Russell's hypochlorite-phenol method for $\mathrm{NH}_{3}$ quantification were prepared as previously reported. ${ }^{[12]}$ The assay was carried out using the modified procedure by Ryan and co-workers described below. ${ }^{[13]}$ A calibration curve was generated by assaying $\mathrm{NH}_{4} \mathrm{Cl}$ standards and measuring the absorbance of indophenolate at $630 \mathrm{~nm}$ by UV/Vis spectroscopy (see Figure S1). Since the assay is normally carried out in water, but $[\mathrm{Fe}(3,5-\mathrm{Me}-$ BAFP) $\left(\mathrm{NH}_{3}\right)_{2}$ ] is not water-soluble, the assay was conducted in a mixture of toluene and water. To ensure that toluene does not interfere with the assay, $\mathrm{NH}_{4} \mathrm{Cl}$ standards were spiked with $0.5 \mathrm{~mL}$ of toluene 
and a calibration curve was generated for these modified conditions. As shown in Figure S1, toluene does not affect the assay. $\left[\mathrm{Fe}(3,5-\mathrm{Me}-\mathrm{BAFP})\left(\mathrm{NH}_{3}\right)_{2}\right]$ was prepared by the reaction of [Fe(3,5-Me-BAFP) $\left.\left(\mathrm{PF}_{6}\right)\right](50 \mathrm{mg})$ and $\mathrm{NH}_{2} \mathrm{OBn}$ (approx. 10 equivalents) in toluene $(3 \mathrm{~mL})$ by stirring the reaction mixture for approx. 2 hours in the glovebox. The solution was then carefully layered with hexanes $(9 \mathrm{~mL})$ and allowed to precipitate at $-30{ }^{\circ} \mathrm{C}$. The next day, the resulting dark red powder was filtered off through a fine frit. The red powder was washed with hexanes to remove any remaining $\mathrm{NH}_{2} \mathrm{OBn}$. $\mathrm{NH}_{3}$ determination was carried out with bulk material of [Fe(3,5-Me-BAFP) $\left.\left(\mathrm{NH}_{3}\right)_{2}\right]$ by the following method. In a typical experiment, $\left[\mathrm{Fe}(3,5-\mathrm{Me}-\mathrm{BAFP})\left(\mathrm{NH}_{3}\right)_{2}\right](5 \mathrm{mg})$ was dissolved in toluene $(0.5 \mathrm{~mL})$ in a round-bottomed flask, which was sealed with a septum in the glovebox. Then the solution was brought out of the glovebox and stirred on ice. In the next step, $\mathrm{HCl}(3.3 \mathrm{~mL} 0.01 \mathrm{M})$, manganese chloride tetrahydrate solution $(250 \mu \mathrm{L}, 0.003 \mathrm{M})$, hypochlorite solution $(0.25 \mathrm{~mL}, 2.1 \mathrm{M})$, and phenol solution $(0.5 \mathrm{~mL}, 3.0 \mathrm{M})$ were added via syringe resulting in the formation of a dark blue solution. Next, the solution (still stirring) was placed in a hot water bath for approx. $5 \mathrm{~min}$. Once cooled to room temperature, an aliquot of the aqueous layer was removed and the absorbance at $630 \mathrm{~nm}$ was measured. The concentration of $\mathrm{NH}_{3}$ was calculated using the calibration curve in Figure S1. The bulk material was assayed three times and the corresponding $\mathrm{NH}_{3}$ concentrations are reported (See Results and Discussion).

Detection of $\mathbf{N}_{\mathbf{2}} \mathbf{O}$ : In a $25 \mathrm{~mL}$ round-bottomed flask, [Fe(3,5-Me-BAFP) $\left.\left(\mathrm{PF}_{6}\right)\right](50 \mathrm{mg})$ was dissolved in 1,2-DCE $(2.5 \mathrm{~mL})$. This round-bottomed flask was sealed with septa and copper-wired to ensure gas could not escape the flask. Then, $\mathrm{NH}_{2} \mathrm{OBn}(92 \mu \mathrm{L})$ in 1,2DCE ( $0.5 \mathrm{~mL}$, approx. 27 equivalents of $\mathrm{NH}_{2} \mathrm{OBn}$ ) was added via syringe. The solution was allowed to stir for $1 \mathrm{~h}$ and $\mathrm{N}_{2} \mathrm{O}$ formation was detected via gas headspace analysis using gas phase IR spectroscopy.

Instrumentation: Infrared spectra were obtained from $\mathrm{KBr}$ disks with a Perkin-Elmer BX spectrometer at room temperature. The resolution was set to $2 \mathrm{~cm}^{-1}$. Electronic absorption spectra were measured using an Analytical Jena Specord 600 instrument at room temperature. Electron paramagnetic resonance spectra were recorded with a Bruker X-band EMX spectrometer equipped with Oxford Instruments liquid nitrogen and helium cryostats. EPR spectra were typically obtained on frozen solutions using $20 \mathrm{~mW}$ microwave power and $100 \mathrm{kHz}$ field modulation with the amplitude set to $1 \mathrm{G}$. Sample concentrations employed were approx. $2 \mathrm{mM}$. Fluorine nuclear magnetic resonance spectra were recorded on a Varian Inova $377 \mathrm{MHz}$ instrument at room temperature.

Crystal Structure Determination: A brown prism of $\left[\mathrm{Fe}(3,5-\mathrm{Me}-\mathrm{BAFP})\left(\mathrm{NH}_{3}\right)_{2}\right]$ of dimensions $0.18 \times 0.09 \times 0.09 \mathrm{~mm}$ was mounted on a Rigaku AFC10K Saturn 944+ CCD-based X-ray diffractometer equipped with a low temperature device and a Micromax$007 \mathrm{HF} \mathrm{Cu}$-target micro-focus rotating anode $(\lambda=1.54187 \AA)$ that operates at $1.2 \mathrm{~kW}$ power $(40 \mathrm{kV}, 30 \mathrm{~mA})$. The X-ray intensities were measured at $85 \mathrm{~K}$ with the detector placed at a distance of $42 \mathrm{~mm}$ from the crystal. Analysis of the data showed negligible decay during data collection; the data were processed with CrystalClear $2.0^{[14]}$ and corrected for absorption. The structure was solved and refined with the Bruker SHELXTL (version 2008/4) software package. ${ }^{[15]}$ Additional details are presented in Table 1 and in the Supporting Information (Tables S1-S4).

Crystallographic data (excluding structure factors) for the structure(s) reported in this paper have been deposited with the Cambridge Crystallographic Data Centre as supplementary publication no. CCDC926652 Copies of the data can be obtained free of charge on applica-
Table 1. Crystal data and structure refinement for [Fe(3,5-Me-BAFP) $\left.\left(\mathrm{NH}_{3}\right)_{2}\right]$.

\begin{tabular}{ll}
\hline Empirical formula & $\mathrm{C}_{115} \mathrm{H}_{106} \mathrm{FeN}_{6} \mathrm{O}_{8}$ \\
\hline Formula weight $/ \mathrm{gmol}^{-1}$ & 1755.91 \\
$T / \mathrm{K}$ & 85 \\
Space group & Monoclinic, $P$ 2(1)/c \\
$a / \AA$ & 21.3278 \\
$b / \AA$ & 27.9938 \\
$c / \AA$ & 15.7510 \\
$\alpha /$ deg. & 90 \\
$\beta /$ deg. & 101.233 \\
$\gamma /$ deg. & 90 \\
$V / \mathrm{A}^{3}$ & 9223.9 \\
$Z$ & 4 \\
$\mu / \mathrm{mm}^{-1}$ & 1.816 \\
$\lambda / \AA$ & 1.54178 \\
Collected reflns & 245071 \\
Unique reflns & 16890 \\
$\mathrm{R}_{\text {int }}$ & 0.0650 \\
$\mathrm{GOF}$ & 1.110 \\
$\mathrm{R} 1[I>2 \sigma(I)]$ & 0.0520 \\
wR2 (all data) & 0.1537 \\
\hline
\end{tabular}

tion to CCDC, 12 Union Road, Cambridge CB2 1EZ, UK [Fax: (internat.) + 44 1223/336-033; E-mail: deposit@ccdc.cam.ac.uk].

Supporting Information (see footnote on the first page of this article): The cartesian coordinates and complete tables of bond lengths and angles of $\left[\mathrm{Fe}(3,5-\mathrm{Me}-\mathrm{BAFP})\left(\mathrm{NH}_{3}\right)_{2}\right], \quad \mathrm{NH}_{4} \mathrm{Cl}$ calibration curves in water and toluene, the UV/Vis and EPR spectra of $\left[\mathrm{Fe}(3,5-\mathrm{Me}-\mathrm{BAFP})\left(\mathrm{PF}_{6}\right)\right]$ and the UV/Vis and EPR spectra of the reaction product upon addition of excess $\mathrm{NH}_{2} \mathrm{OBn}$ to $\left[\mathrm{Fe}(3,5-\mathrm{Me}-\mathrm{BAFP})\left(\mathrm{PF}_{6}\right)\right]$ are provided in the Supporting Information.

\section{Results and Discussion}

The bis-picket fence porphyrin, $\mathrm{H}_{2}$ [3,5-Me-BAFP], was synthesized in three steps in an overall yield of $10 \%$ by literature protocols. ${ }^{[10]} \mathrm{Next}$, the complex [Fe(3,5-Me-BAFP) $\left.(\mathrm{Cl})\right]$ was prepared by metallation of $\mathrm{H}_{2}[3,5-\mathrm{Me}-\mathrm{BAFP}]$ with $\mathrm{FeCl}_{2}$ in refluxing DMF in $67 \%$ yield. This was followed by reaction with $\mathrm{AgClO}_{4}$ in refluxing 2-Me-THF to afford $\left[\mathrm{Fe}(3,5-\mathrm{Me}-\mathrm{BAFP})\left(\mathrm{ClO}_{4}\right)\right](\mathbf{1})$ in $62 \%$ yield. The ferric complex $\left[\mathrm{Fe}(3,5-\mathrm{Me}-\mathrm{BAFP})\left(\mathrm{PF}_{6}\right)\right](2)$ was synthesized in the same way using $\mathrm{AgPF}_{6}$ in $78 \%$ yield. The purity of these complexes was assessed by UV/Vis, IR, and EPR spectroscopy. The UV/ Vis spectrum of the precursor complex $\mathbf{1}$ exhibits the Soret band at $416 \mathrm{~nm}$ and a prominent $\mathrm{Q}$ band at $518 \mathrm{~nm}$ in toluene as shown in Figure 1. Upon addition of excess $\mathrm{NH}_{2} \mathrm{OBn}$, the Soret band shifts immediately to $433 \mathrm{~nm}$ and the main Q band is now observed at $537 \mathrm{~nm}$. These changes are accompanied by a dramatic sharpening of the Soret band. These spectral changes are characteristic for the formation of a ferrous porphyrin complex as the reaction product. Similar spectral changes occur when 2 is reacted with excess $\mathrm{NH}_{2} \mathrm{OBn}$ (see Figure S2). 


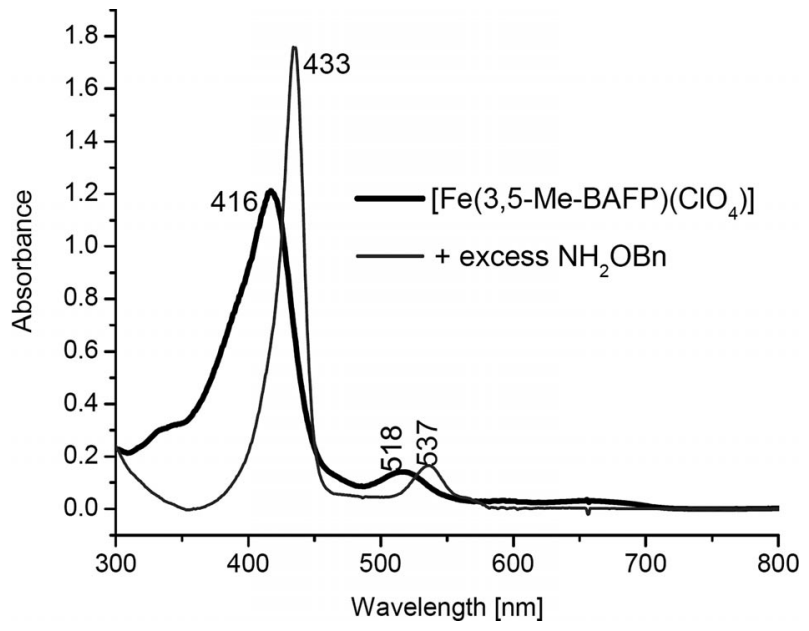

Figure 1. UV/Vis spectra of $\left[\mathrm{Fe}(3,5-\mathrm{Me}-\mathrm{BAFP})\left(\mathrm{ClO}_{4}\right)\right]$ (black) and of the product of the reaction of this complex with excess $\mathrm{NH}_{2} \mathrm{OBn}$ (grey) in toluene at room temperature.

In order to detect intermediates in the reaction of [Fe(3,5-Me-BAFP) $\left.\left(\mathrm{PF}_{6}\right)\right]$ with $\mathrm{NH}_{2} \mathrm{OBn}$ a number of experiments were completed. The reaction of stoichiometric amounts of $\mathrm{NH}_{2} \mathrm{OBn}$ (ie. 1 and 2 equivalents) with $\left[\mathrm{Fe}(3,5-\mathrm{Me}-\mathrm{BAFP})\left(\mathrm{PF}_{6}\right)\right]$ was explored via UV/Vis spectroscopy (at room temperature). The obtained UV/Vis spectra correspond to a mixture of the starting ferric porphyrin complex and the ferrous product (see below for further characterization). Based on this, it is not possible to observe any potential ferric porphyrin intermediates at room temperature. In addition, kinetic experiments monitored by UV/Vis spectroscopy were attempted to obtain a rate constant for the reaction of [Fe(3,5-Me-BAFP) $\left.\left(\mathrm{PF}_{6}\right)\right]$ with excess $\mathrm{NH}_{2} \mathrm{OBn}$ (approx. 27 equivalents). However, this reaction is complete within mixing time of the solutions, so stopped-flow spectroscopy will have to be employed to determine the rate constant. This will be the focus of additional, future studies. Lastly, we tested whether $\mathrm{N}_{2} \mathrm{O}$ is a product of the reaction of [Fe(3,5-Me-BAFP) $\left.\left(\mathrm{PF}_{6}\right)\right]$ with excess $\mathrm{NH}_{2} \mathrm{OBn}$ as shown earlier for the reaction of ferric porphyrins with $\mathrm{NH}_{2} \mathrm{OH}$ (see above). Indeed, gas headspace analysis by IR spectroscopy confirms that $\mathrm{N}_{2} \mathrm{O}$ is a product in addition to $\mathrm{NH}_{3}\left(0.175\right.$ equivalents of $\mathrm{N}_{2} \mathrm{O}$ (relative to the porphyrin complex) were detected).

To further confirm that the product of the reaction of $\mathbf{1}$ and 2 with $\mathrm{NH}_{2} \mathrm{OBn}$ is a ferrous porphyrin, EPR spectroscopy was employed. The EPR spectrum of $\mathbf{1}$ in toluene at $10 \mathrm{~K}$, shown in Figure 2, exhibits effective $g_{\perp}$ values of 5.8 and 4.6 and an effective $\mathrm{g}_{\|}$value of 2.0. This is indicative of a complex with a $S=5 / 2,3 / 2$ spin-admixed ground state, which typically have effective $g_{\perp}$ values that range from 4 to $6\left(g_{\|}=2\right) .{ }^{[16]}$ Also, these $S=5 / 2,3 / 2$ spin-admixed species are commonly observed for ferric porphyrin perchlorate complexes, ${ }^{[11,17]}$ where the effective $g_{\perp}$ values then vary depending on the relative amounts of $S=5 / 2$ and $3 / 2$ in the ground state. For example, $\left[\mathrm{Fe}(\mathrm{TPP})\left(\mathrm{ClO}_{4}\right)\right]$, in toluene at $10 \mathrm{~K}$ has an effective $\mathrm{g}_{\perp}$ of 4.70 $\left(\mathrm{g}_{\|}=1.98\right),{ }^{[11]}$ while $\left[\mathrm{Fe}(\mathrm{OEP})\left(\mathrm{ClO}_{4}\right)\right]$, in a dichloromethane/ toluene mixture at $77 \mathrm{~K}$, has a significantly shifted effective $\mathrm{g}_{\perp}$ value of $3.83\left(\mathrm{~g}_{\|}=1.97\right) .{ }^{[17]}$ Interestingly, the EPR spectrum of 2 in 2-Me-THF at $6 \mathrm{~K}$ shows a similar $S=5 / 2,3 / 2$ spinadmixed ground state with effective $g_{\perp}$ values of 6.0 and 5.2 and an effective $g_{\|}$value of 2.0 (see Figure S3). This is again in agreement with literature g-values for ferric porphyrin hexafluorophosphate complexes. For example, $\left[\mathrm{Fe}(\mathrm{TPP})\left(\mathrm{PF}_{6}\right)\right]$ in toluene at $10 \mathrm{~K}$ shows an effective $\mathrm{g}_{\perp}$ value of approx. 5. ${ }^{[11]}$ These results indicate that 2 has a dominant $S=5 / 2$ contribution in the ground state, as the effective $g_{\perp}$ values are close to those expected for high-spin ferric hemes.

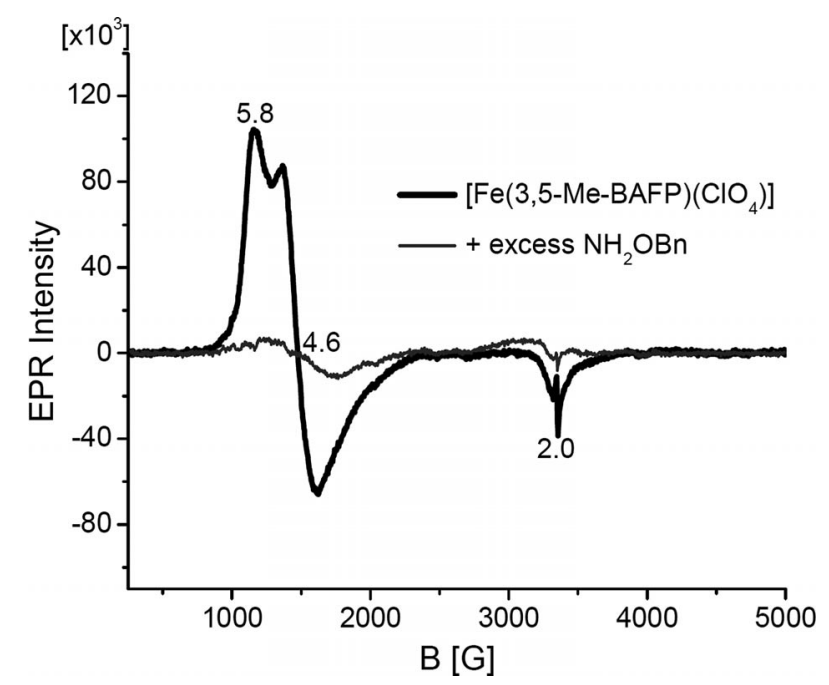

Figure 2. EPR spectra of $\left[\mathrm{Fe}(3,5-\mathrm{Me}-\mathrm{BAFP})\left(\mathrm{ClO}_{4}\right)\right]$ (black) and of the product of the reaction of this complex with excess $\mathrm{NH}_{2} \mathrm{OBn}$ (grey) in toluene. Spectra were measured at $10 \mathrm{~K}$.

Reaction of $\mathrm{NH}_{2} \mathrm{OBn}$ (excess) with either ferric porphyrin complex results in a completely silent EPR spectrum, indicative of the formation of a ferrous porphyrin. This shows that the counterion, $\mathrm{ClO}_{4}{ }^{-}$vs. $\mathrm{PF}_{6}{ }^{-}$, does not affect the formation of the ferrous reaction product. As previously mentioned, Feng and Ryan observed that the reaction of $[\mathrm{Fe}(\mathrm{TPP})(\mathrm{Cl})]$ with excess $\mathrm{NH}_{2} \mathrm{OH}$ at $-30{ }^{\circ} \mathrm{C}$ also led to the reduction of the complex, generating a ferrous product proposed to be $\left[\mathrm{Fe}(\mathrm{TPP})\left(\mathrm{NH}_{2} \mathrm{OH}\right)_{2}\right] \cdot{ }^{[8]}$ As such, we hypothesized that our reaction product was $\left[\mathrm{Fe}(3,5-\mathrm{Me}-\mathrm{BAFP})\left(\mathrm{NH}_{2} \mathrm{OBn}\right)_{2}\right]$. In order to further determine the nature of the product, in particular in the light of another paper that reported hydroxylamine disproportionation by ferrous hemes, ${ }^{[6 \mathrm{~b}]}$ we set up crystallizations of 1 in the presence of excess $\mathrm{NH}_{2} \mathrm{OBn}$. This resulted in the formation of brown prisms, suitable for X-ray crystallography.

The resulting crystal structure shows a six-coordinate heme complex with two small ligands, likely $\mathrm{H}_{2} \mathrm{O}$ or $\mathrm{NH}_{3}$, bound in the axial positions to the heme. However, X-ray crystallography cannot differentiate between $\mathrm{NH}_{3}$ and $\mathrm{H}_{2} \mathrm{O}$, so verification that the bound ligands were in fact both $\mathrm{NH}_{3}$ was obtained from Russell's hypochlorite-phenol method for $\mathrm{NH}_{3}$ quantification. A calibration curve was first generated by assaying $\mathrm{NH}_{4} \mathrm{Cl}$ standards and measuring the absorbance of indophenolate at $630 \mathrm{~nm}$ by UV/Vis spectroscopy. Since the ferrous product species is not water soluble, the assay was completed in toluene, and $\mathrm{NH}_{4} \mathrm{Cl}$ standards were spiked with 
toluene to ensure that toluene does not interfere with $\mathrm{NH}_{3}$ quantification (see Figure S1). To assay the potential product [Fe(3,5-Me-BAFP) $\left.\left(\mathrm{NH}_{3}\right)_{2}\right](3)$, the $\mathrm{NH}_{3}$ is trapped by addition of excess dilute acid to a stirring solution of this complex on ice. The assay was carried out using bulk material of the reaction product and repeated three times. From this assay, we determined that two equivalents of $\mathrm{NH}_{3}$ are bound to the ferrous porphyrin complex, as shown in Table 2 . Hence, the product of the reaction is clearly $\mathbf{3}$, which is the first structurally characterized ferrous porphyrin ammonia complex.

Table 2. $\mathrm{NH}_{3}$ concentrations determined from the assay of the bulk material of $\left[\mathrm{Fe}(3,5-\mathrm{Me}-\mathrm{BAFP})\left(\mathrm{NH}_{3}\right)_{2}\right]$. The theoretical $\left[\mathrm{NH}_{3}\right]$ is based on the amount of $\left[\mathrm{Fe}(3,5-\mathrm{Me}-\mathrm{BAFP})\left(\mathrm{NH}_{3}\right)_{2}\right]$ used in the assay.

\begin{tabular}{lll}
\hline Theoretical $\left[\mathrm{NH}_{3}\right] / \mathrm{mM}$ & Detected $\left[\mathrm{NH}_{3}\right] / \mathrm{mM}$ & Equiv. of $\mathrm{NH}_{3}$ \\
\hline 6.48 & 6.39 & 1.97 \\
6.73 & 6.53 & 1.94 \\
8.42 & 8.25 & 1.96 \\
\hline
\end{tabular}

The structure of the ferrous bis-ammonia complex $\mathbf{3}$ is shown in Figure 3. The two $\mathrm{Fe}-\mathrm{NH}_{3}$ bond lengths are 2.016 and $1.990 \AA$, and $\mathrm{Fe}-\mathrm{N}$ bond lengths of the porphyrin are given in Table 3, which are in agreement with a low-spin ferrous heme (1.981-2.001 $\AA$ ). ${ }^{[18]}$ While the slight difference in $\mathrm{Fe}-\mathrm{NH}_{3}$ bond lengths was unexpected, the packing of the phenolate pickets of 3,5-Me-BAFP ${ }^{2-}$ (approx. $3 \AA$ away from the

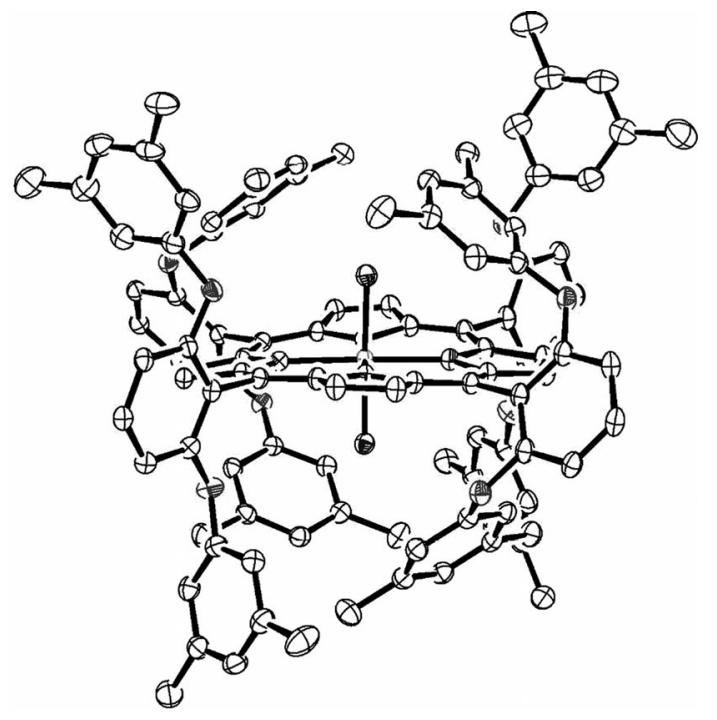

Figure 3. Crystal structure of $\left[\mathrm{Fe}(3,5-\mathrm{Me}-\mathrm{BAFP})\left(\mathrm{NH}_{3}\right)_{2}\right]$. Hydrogen atoms and a solvent molecule (toluene) are omitted for clarity. Thermal ellipsoids are shown at $30 \%$ probability. nitrogen atom of $\mathrm{NH}_{3}$ ) around the $\mathrm{NH}_{3}$ ligands and minor saddling of the heme could modulate this difference. Note that the two $\mathrm{Fe}-\mathrm{NH}_{3}$ bonds in the crystal structure are not symmetry equivalent, due to the presence of the pickets. This results in slightly different microenvironments for each ammonia ligand leading to slightly different $\mathrm{Fe}-\mathrm{NH}_{3}$ bond lengths. Surprisingly, there are no reported crystal structures of $\mathrm{NH}_{3}$-bound ferrous (or ferric) porphyrin complexes in the Cambridge Structural Database. Crystal structures of water-bound ferrous $^{[19]}$ and ferric ${ }^{[20]}$ porphyrin complexes are available, with $\mathrm{Fe}-\mathrm{OH}_{2}$ bonds lengths that range from 1.976-2.099 $\AA$. For structural comparison, there is one reported crystal structure of a six-coordinate ferrous bis-aqua complex $\left[\mathrm{Fe}\left(\mathrm{TDCP}\left(\mathrm{NO}_{2}\right)_{8} \mathrm{P}\right)\left(\mathrm{H}_{2} \mathrm{O}\right)_{2}\right]$ (where $\mathrm{TDCP}\left(\mathrm{NO}_{2}\right)_{8} \mathrm{P}=$ dianion of tetra(2,6-dichlorophenyl)-2,3,7,8,12,13,17,18-octanitro-porphyrin). ${ }^{[19]}$ The $\mathrm{Fe}-\mathrm{OH}_{2}$ bond lengths are both $1.976 \AA$ and the average $\mathrm{Fe}-\mathrm{N}$ distance of the porphyrin is $1.945 \AA$, as shown in Table 3 . The bound $\mathrm{H}_{2} \mathrm{O}$ ligands are each hydrogenbonded to one acetone molecule. Also, it should be mentioned that this ferrous porphyrin complex has a non-planar, ruffled structure and is likely intermediate spin based on the average $\mathrm{Fe}-\mathrm{N}$ distances of the porphyrin. ${ }^{[18]}$ In addition, there are reported crystal structures of six-coordinate bis(primary amine) ferrous porphyrins $\left[\mathrm{Fe}(\mathrm{TPP})\left(\mathrm{RNH}_{2}\right)_{2}\right]$, where $\mathrm{RNH}_{2}=1$-butylamine, benzylamine, and phenethylamine. ${ }^{[21]}$ These ferrous porphyrin complexes are low-spin and the $\mathrm{Fe}-\mathrm{NH}_{2} \mathrm{R}$ bond lengths $\left(2.028-2.045 \AA\right.$ ) are longer than the $\mathrm{Fe}-\mathrm{NH}_{3}$ bond lengths in 3 (see Table 3 ). The average $\mathrm{Fe}-\mathrm{N}$ distances of the porphyrin for $\mathbf{3}$ and for these bis(primary amine) ferrous porphyrins are in good agreement with each other.

In addition, there are two reports of $\mathrm{NH}_{3}$-bound iron porphyrin complexes with $\mathrm{TPP}^{2-}$ and $\mathrm{OEP}^{2-}$ coligands. The ferric complex $\left[\mathrm{Fe}(\mathrm{TPP})\left(\mathrm{NH}_{3}\right)_{2}\right]^{+}$was characterized by ${ }^{1} \mathrm{H} \mathrm{NMR}$, EPR, and Mössbauer spectroscopy. $\left[\mathrm{Fe}(\mathrm{TPP})\left(\mathrm{NH}_{3}\right)\right]^{+}$is low spin and stable with respect to $\mathrm{NH}_{3}$ loss. A broad resonance is observed at approx. $241 \mathrm{ppm}$ for coordinated $\mathrm{NH}_{3}$ in the ${ }^{1} \mathrm{H}-\mathrm{NMR}$ spectrum. ${ }^{[22]}$ With $\mathrm{OEP}^{2-}$, the ferrous complex $\left[\mathrm{Fe}(\mathrm{OEP})\left(\mathrm{NH}_{3}\right)_{2}\right]$ was prepared and studied in solution using Mössbauer spectroscopy. ${ }^{[18]}$ This ferrous porphyrin complex is also low-spin as evident from the Mössbauer data. With this, our crystal structure of $\mathbf{3}$ is the first reported structure of an $\mathrm{NH}_{3}$-bound ferrous heme model complex. One could envision that the bis-picket fence porphyrin could facilitate $\mathrm{NH}_{3}$ binding by "trapping" it due to steric protection of the binding site by the picket fence.

Experimentally, the addition of excess $\mathrm{NH}_{2} \mathrm{OBn}$ to our ferric porphyrin complexes at room temperature does not lead to the

Table 3. Selected bond lengths for $\left[\mathrm{Fe}(3,5-\mathrm{Me}-\mathrm{BAFP})\left(\mathrm{NH}_{3}\right)_{2}\right]$, $\left[\mathrm{Fe}\left(\mathrm{TDCP}\left(\mathrm{NO}_{2}\right)_{8} \mathrm{P}\right)\left(\mathrm{H}_{2} \mathrm{O}\right)_{2}\right]$, [ $\left.\mathrm{Fe}(\mathrm{TPP})(1-\mathrm{BuNH})_{2}\right]$, $\left[\mathrm{Fe}(\mathrm{TPP})(\mathrm{BzNH})_{2}\right]$, and $\left[\mathrm{Fe}(\mathrm{TPP})\left(\mathrm{PhCH}_{2} \mathrm{CH}_{2} \mathrm{NH}_{2}\right)_{2}\right]^{a}{ }^{a}$

\begin{tabular}{lllll}
\hline Complex & $\Delta \mathrm{Fe}-\mathrm{N}_{\text {por }}{ }^{c}$ & $\Delta \mathrm{Fe}-\mathrm{L}$ & $\Delta \mathrm{Fe}-\mathrm{L}$ & Reference \\
\hline$\left[\mathrm{Fe}(3,5-\mathrm{Me}-\mathrm{BAFP})\left(\mathrm{NH}_{3}\right)_{2}\right]^{b}$ & 1.992 & 1.990 & 2.016 & this work \\
{$\left[\mathrm{Fe}\left(\mathrm{TDCP}\left(\mathrm{NO}_{2}\right)_{8} \mathrm{P}\right)\left(\mathrm{H}_{2} \mathrm{O}\right)_{2}\right]$ (distorted) } & 1.945 & 1.976 & 1.976 & {$[19]$} \\
{$\left[\mathrm{Fe}(\mathrm{TPP})\left(1-\mathrm{BuNH}_{2}\right)_{2}\right]$} & 1.989 & 2.039 & 2.039 & {$[21]$} \\
{$\left[\mathrm{Fe}(\mathrm{TPP})\left(\mathrm{BzNH}_{2}\right)_{2}\right]$} & 1.992 & 2.041 & 2.045 & {$[21]$} \\
{$\left[\mathrm{Fe}(\mathrm{TPP})\left(\mathrm{PhCH}_{2} \mathrm{CH}_{2} \mathrm{NH}_{2}\right)_{2}\right]$} & 1.989 & 2.028 & 2.028 & {$[21]$} \\
\hline
\end{tabular}

a) All values are given in $\AA$. b) A complete table of bond lengths and angles is given in the Supporting Information. c) Average value. 


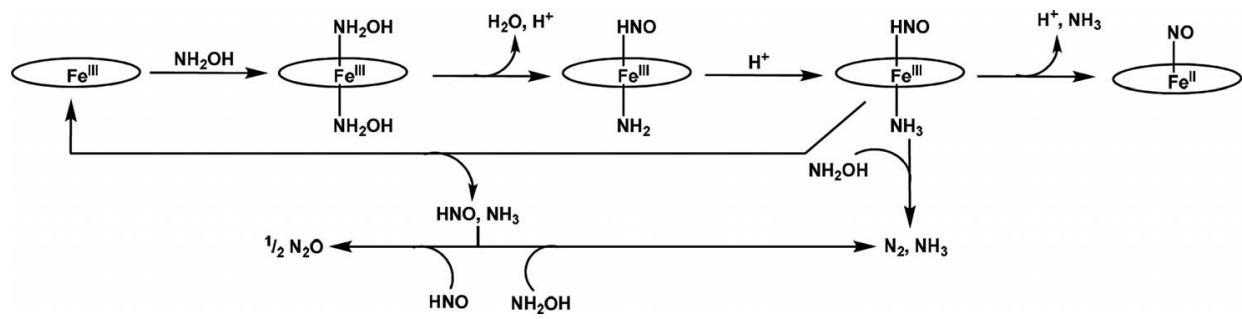

Figure 4. Proposed disproportionation mechanism of $\mathrm{NH}_{2} \mathrm{OH}$ by ferric porphyrin complexes, derived from the reaction of [Fe(TPPS) ${ }^{3-}$ with excess $\mathrm{NH}_{2} \mathrm{OH}$. This mechanism is adapted from Ref. [6b].

formation of a ferrous heme-nitrosyl product, as in Feng and Ryan's work (see Introduction). In the latter case, the ferrous heme-nitrosyl is proposed to form via a reductive nitrosylationtype mechanism, for example:

$$
\begin{aligned}
& {[\mathrm{Fe}(\mathrm{TPP}) \mathrm{Cl}]+2 \mathrm{NH}_{2} \mathrm{OH} \rightarrow\left[\mathrm{Fe}(\mathrm{TPP})\left(\mathrm{NH}_{2} \mathrm{OH}\right)_{2}\right]^{+}+\mathrm{Cl}^{-}} \\
& {\left[\mathrm{Fe}(\mathrm{TPP})\left(\mathrm{NH}_{2} \mathrm{OH}\right)_{2}\right]^{+}+\mathrm{NH}_{2} \mathrm{OH} \rightarrow \underset{[\mathrm{Fe}(\mathrm{TPP})(\mathrm{NO})]+}{\mathrm{NH}_{3}+\mathrm{NH}_{3} \mathrm{OH}^{+}+\mathrm{H}_{2} \mathrm{O}}}
\end{aligned}
$$

In this mechanism, the coordinated $\mathrm{NH}_{2} \mathrm{OH}$ ligand is oxidized to $\mathrm{NO}$ and an additional molecule of $\mathrm{NH}_{2} \mathrm{OH}$ is reduced to $\mathrm{NH}_{3} \cdot{ }^{[8]}$ This result differs from the report by Bari et al., who did not observe quantitative formation of the ferrous heme-nitrosyl from the reaction of $[\mathrm{Fe}(\mathrm{TPPS})]^{3-}$ with excess $\mathrm{NH}_{2} \mathrm{OH}$, and the gaseous products $\mathrm{N}_{2}$ and $\mathrm{N}_{2} \mathrm{O}$ were also detected. The proposed mechanism of this reaction is shown in Figure 4. In this case, Bari et al. suggest that $\mathrm{NH}_{2} \mathrm{OH}$ is disproportionated to generate the ferric intermediate $\left[\mathrm{Fe}(\mathrm{TPPS})(\mathrm{HNO})\left(\mathrm{NH}_{3}\right)\right]^{3-}$, followed by oxidation of the HNO ligand by the ferric heme and loss of coordinated $\mathrm{NH}_{3}$ to give the corresponding ferrous heme-nitrosyl complex $[\mathrm{Fe}(\mathrm{TPPS})(\mathrm{NO})]^{4-}$. However, there are other parallel mechanistic pathways that must also occur to explain the generation of $\mathrm{N}_{2}$ and $\mathrm{N}_{2} \mathrm{O}$. For example, the HNO ligand from the ferric intermediate $\left[\mathrm{Fe}(\mathrm{TPPS})(\mathrm{HNO})\left(\mathrm{NH}_{3}\right)\right]^{3-}$ could react with excess $\mathrm{NH}_{2} \mathrm{OH}$ to produce $\mathrm{N}_{2}$. The generation of $\mathrm{N}_{2} \mathrm{O}$ could occur by loss of coordinated $\mathrm{HNO}$ from $\left[\mathrm{Fe}(\mathrm{TPPS})(\mathrm{HNO})\left(\mathrm{NH}_{3}\right)\right]^{3-}$, followed by reaction of two molecules of $\mathrm{HNO}$ to form hyponitrous acid $\left(\mathrm{N}_{2} \mathrm{O}_{2} \mathrm{H}_{2}\right)$, which decomposes into $\mathrm{N}_{2} \mathrm{O}$ and $\mathrm{H}_{2} \mathrm{O}$. The latter process regenerates the starting ferric porphyrin complex and the cycle can start over again.

In contrast to these findings, a reduction of the ferric porphyrin to the ferrous state is observed in our case, followed by $\mathrm{NH}_{2} \mathrm{OBn}$ disproportionation to generate $\mathrm{NH}_{3}$ and benzyl alcohol and the additional gaseous products $\mathrm{N}_{2}$ and $\mathrm{N}_{2} \mathrm{O}$. This leads ultimately to the formation of an ammonia-bound ferrous heme complex, rather than $\left[\mathrm{Fe}(3,5-\mathrm{Me}-\mathrm{BAFP})\left(\mathrm{NH}_{2} \mathrm{OBn}\right)_{2}\right]$ or [Fe(3,5-Me-BAFP)(NO)]. Therefore, the findings reported in this paper parallel observations by Bari et al. for the reaction of excess $\mathrm{NH}_{2} \mathrm{OH}$ with the ferric heme complex $[\mathrm{Fe}(\mathrm{TEPyP})]^{5+} \cdot{ }^{[6 \mathrm{~b}]}$ Interestingly, the UV/Vis spectra after the addition of excess $\mathrm{NH}_{2} \mathrm{OBn}$ to $\mathbf{1}$ or $\mathbf{2}$ are similar to the UV/Vis spectrum that results from $\mathrm{NH}_{2} \mathrm{OH}$ addition to $[\mathrm{Fe}(\mathrm{TEPyP})]^{5+}$ with a Soret band at $425 \mathrm{~nm}$ and the main Q band at $535 \mathrm{~nm}$. Therefore, addition of $\mathrm{NH}_{2} \mathrm{OH}$ to
$[\mathrm{Fe}(\mathrm{TEPyP})]^{5+}$ results in a similar reduction of the iron from the ferric to the ferrous oxidation state as reported here, evidenced by UV/Vis and ${ }^{1} \mathrm{H}-\mathrm{NMR}$ spectroscopy. Also, Bari et al. showed free-radical formation in this reaction by the methyl metacrylate assay. In their proposed mechanism in Figure 5, reduction of the ferric porphyrin complex generates a six-coordinate hydroxylamine-bound ferrous porphyrin complex and a nitrogen-containing radical species in the first step of the reaction. The nitrogen-containing radical species, $\mathrm{NH}_{2} \mathrm{O}$ (radical), initiates the formation of $\mathrm{HNO}$ and other radical species, such as $\mathrm{NH}_{2}$ (radical). These species could then generate $\mathrm{NH}_{3}$ as well as $\mathrm{N}_{2}$ and $\mathrm{N}_{2} \mathrm{O}$ as shown in Figure 5. One could envision that the $\mathrm{NH}_{2}$ (radical) or $\mathrm{N}_{2} \mathrm{H}_{4}$ could also oxidize the ferrous porphyrin back to the ferric oxidation state, and the catalytic cycle could start over again. This is in accordance with the findings by Bari et al. for $[\mathrm{Fe}(\mathrm{TEPyP})]^{5+}$, as they observe the porphyrin to be catalytically active in $\mathrm{NH}_{2} \mathrm{OH}$ disproportionation. Overall, our findings are in good agreement with the work of Bari et al. as reported in Ref. [6b].

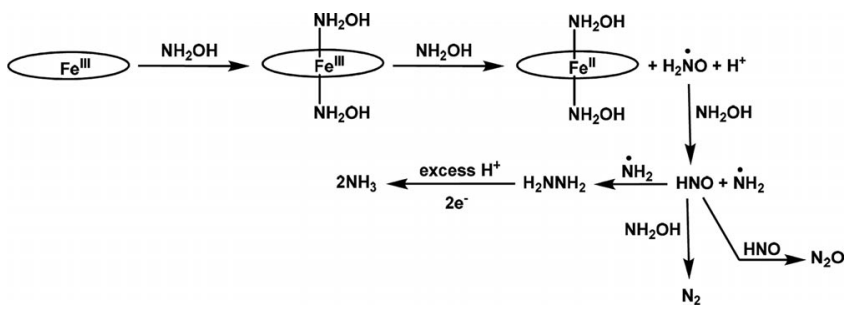

Figure 5. Proposed disproportionation mechanism of $\mathrm{NH}_{2} \mathrm{OH}$ by ferric porphyrin complexes, derived from the reaction of $[\mathrm{Fe}(\mathrm{TEPyP})]^{5+}$ with excess $\mathrm{NH}_{2} \mathrm{OH}$. This mechanism is adapted from Ref. [6b].

\section{Summary}

In this study, the two new ferric bis-picket fence porphyrin complexes $\left[\mathrm{Fe}(3,5-\mathrm{Me}-\mathrm{BAFP})\left(\mathrm{ClO}_{4}\right)\right]$ and $\left[\mathrm{Fe}(3,5-\mathrm{Me}-\mathrm{BAFP})\left(\mathrm{PF}_{6}\right)\right]$ have been prepared and characterized by UV/Vis and EPR spectroscopy. The reactivity of these ferric porphyrin complexes with $\mathrm{NH}_{2} \mathrm{OBn}$ was studied as a model for $\mathrm{NH}_{2} \mathrm{OH}$. When these ferric porphyrin complexes are reacted with excess $\mathrm{NH}_{2} \mathrm{OBn}$ a reduction of the iron from the ferric to the ferrous oxidation state occurs, followed by disproportionation of $\mathrm{NH}_{2} \mathrm{OBn}$. The final product of this reaction is $\left[\mathrm{Fe}(3,5-\mathrm{Me}-\mathrm{BAFP})\left(\mathrm{NH}_{3}\right)_{2}\right]$, which was characterized by $\mathrm{X}$-ray crystallography. This complex constitutes the first bisammonia complex of a ferrous or ferric heme structurally characterized to date. 


\section{Acknowledgments}

This work was supported by a grant from the National Science Foundation (CHE-0846235). We acknowledge Dr. Jeff W. Kampf (University of Michigan) for his X-ray crystallographic analysis of [Fe(3,5-Me-BAFP) $\left.\left(\mathrm{NH}_{3}\right)_{2}\right]$.

\section{References}

[1] a) P. Gross, R. P. Smith, Crit. Rev. Toxicol. 1985, 14, 87; b) C. P. Chang, S. P. Pan, M. T. Lin, Br. J. Pharm. 2001, 132, 1524; c) M. T. Lin, S. P. Pan, L. J. Hu, Y. L. Yang, Br. J. Pharmacol. 1999, 127, 1511 .

[2] S. J. Ferguson, J. Curr. Opin. Chem. Bio. 1998, 2, 182.

[3] A. B. Hooper, A. Nason, J. Biol. Chem. 1965, 240, 4044.

[4] K. K. Andersson, A. B. Hooper, FEBS Lett. 1983, 164, 236.

[5] B. R. Crane, L. M. Siegel, E. D. Getzoff, Biochemistry 1997, 36, 12101.

[6] a) G. E. Alluisetti, A. E. Almaraz, V. T. Amorebieta, F. Doctorovich, J. A. Olabe, J. Am. Chem. Soc. 2004, 126, 13432; b) S. E. Bari, V. T. Amorebieta, M. M. Gutierrez, J. A. Olabe, F. Doctorovich, J. Inorg. Biochem. 2010, 104, 30; c) I. C. Choi, Y. Liu, Z. Wei, M. D. Ryan, Inorg. Chem. 1997, 36, 3113; d) M. Gutierrez, J. A. Olabe, V. T. Amorebieta, Inorg. Chem. 2011, 50, 8817; e) S. K. Wolfe, C. Andrade, J. H. Swinehart, Inorg. Chem. 1974, 13, 2567.

[7] a) V. R. Nast, I. Foppl, Z. Anorg. Allg. Chem. 1950, 263, 310; b) F. T. Bonner, L. S. Dzelzkalns, J. A. Bonucci, Inorg Chem. 1978, 17, 2487.

[8] D. Feng, M. D. Ryan, Inorg. Chem. 1987, 26, 2480.
[9] L. Falborg, K. A. Jorgensen, J. Chem. Soc. Perkin Trans. 1 1996, 2823.

[10] L. E. Goodrich, R. Saikat, E. Alp, J. Zhao, M. Y. Hu, N. Lehnert, Inorg. Chem. 2013, 52, accepted for publication.

[11] C. Reed, T. Mashiko, S. Bentley, M. Kastner, R. Scheidt, K. Spartalian, G. Lang, J. Am. Chem. Soc. 1979, 101, 2948.

[12] J. Russell, J. Biol. Chem. 1944, 156, 457.

[13] I. K. Choi, Y. Liu, D. Feng, K. J. Paeng, M. D. Ryan, Inorg. Chem. 1991, 30, 1832.

[14] CrystalClear Expert 2.0 r12, Rigaku Americas and Rigaku Corporation: Rigaku Americas, 9009, TX, USA 77381-5209, Rigaku Tokyo, 196-8666, Japan, 2011.

[15] G. M. Sheldrick, SHELXTL, v. 2008/4; Bruker Analytical X-ray: Madison, WI, USA, 2008

[16] a) D. R. Evans, C. A. Reed, J. Am. Chem. Soc. 2000, 122, 4660; b) W. E. Blumberg, Methods Enzymol. 1981, 76, 312.

[17] E. T. Kitner, J. H. Dawson, Inorg. Chem. 1991, 30, 4892.

[18] R. W. Scheidt, C. A. Reed, Chem. Rev. 1981, 81, 543.

[19] K. M. Barkigia, M. Palacio, Y. Sun, M. Nogues, M. W. Renner, F. Varret, P. Battioni, D. Mansuy, J. Fajer, Inorg. Chem. 2002, 41.

[20] a) R. W. Scheidt, T. Mashiko, C. A. Reed, J. Am. Chem. Soc. 1978, 100, 666; b) R. Patra, A. Chaudhary, S. K. Ghosh, P. R. Sankar, Inorg. Chem. 2008, 47, 8324; c) T. La, G. M. Miskelly, R. Bau, Inorg. Chem. 1997, 36, 5321; d) I. Hijazi, T. Roisnel, P. Even-Hernandez, F. Geneste, O. Cador, T. Guizouarn, B. Boitrel, Inorg. Chem. 2010, 49, 7536; e) F. C. F. Korber, J. R. Lindsay Smith, S. Prince, P. Rizkallah, C. D. Reynolds, D. R. Shawcross, J. Chem. Soc., Dalton Trans. 1991, 3291.

[21] O. Q. Munro, P. S. Madlala, R. A. F. Warby, T. B. Seda, H. Giovanni, Inorg. Chem. 1999, 38, 4724.

[22] Y. O. Kim, H. M. Goff, Inorg. Chem. 1990, 29, 3907.

Received: February 27, 2013 Published Online: May 27, 2013 